\title{
Structural Effect of Several Acyclic Neutral Carriers Containing 8-Quinolyloxy Units on the Stability Constants of Their $\mathrm{Li}^{+}$Complexes in Water-Saturated Nitrobenzene
}

\author{
Yoshihiro Kudo*, Takeshi MiYaKawa*, Yasuyuki TaKedA*, \\ Hiroaki Matsuda* and Kazuhisa HiratanI** \\ *Department of Chemistry, Faculty of Science, Chiba University, \\ Yayoi, Inage, Chiba 263, Japan \\ **National Institute of Materials and Chemical Research, Tsukuba, Ibaraki 305, Japan
}

\begin{abstract}
The stability constants $\left(\beta_{1}^{\mathrm{NB}}(\mathrm{M}) / \mathrm{mol}^{-1} \mathrm{dm}^{3}\right)$ of $1: 1$ complexes of $\mathrm{M}^{+}\left(=\mathrm{Li}^{+}, \mathrm{Na}^{+}\right)$with 1,3-bis(8-quinolyloxy)propane (IV), 1,4-bis(8-quinolyloxy)butane (V) and 3,3-bis[(7-methyl-8-quinolyloxy)methyl]oxetane (VI) were determined by iontransfer polarography in water-saturated nitrobenzene (NB) at $25^{\circ} \mathrm{C}$. Their logarithmic values were on the order of VI $(4.6)<\mathrm{V}(5.7)<\mathrm{IV}(7.4)$ for $\mathrm{M}=\mathrm{Li}$ and $\mathrm{VI}(3.9)<\mathrm{V}(4.5)<\mathrm{IV}(5.7)$ for $\mathrm{M}=\mathrm{Na}$. This order shows that the stability of the $\mathrm{Li}^{+}$and $\mathrm{Na}^{+}$complexes significantly increases when the carrier can form a four-coordinate structure similar to that of a tetradentate 14-crown-4 in their complexes. The potentiometric selectivity coefficients $\left(k_{\mathrm{LiNa}}^{\text {pot }}\right)$ of IV $-\mathrm{VI}$ for $\mathrm{Li}^{+}$against $\mathrm{Na}^{+}$were calculated based on the $\beta_{1}^{\mathrm{NB}}(\mathrm{M})$-values using the equation $\log k_{\mathrm{LiNa}}^{\mathrm{pot}}=0.70+\log \left[\beta_{1}^{\mathrm{NB}}(\mathrm{Na}) / \beta_{1}^{\mathrm{NB}}(\mathrm{Li})\right]$, and the results compared with those previously described for other bis(8-quinolyloxy)propane derivatives.
\end{abstract}

Keywords Stability constant, $\mathrm{Li}^{+}$selectivity, bis(8-quinolyloxy)alkane, water/nitrobenzene interface, ion-transfer polarography

Considerable attention has been focused on $\mathrm{Li}^{+}$ selective electrodes as a tool for the potentiometric determination of $\mathrm{Li}^{+}$activity in biological and environmental samples. ${ }^{1}$ In monitoring the $\mathrm{Li}^{+}$activity during therapy for manic-depressive illness ${ }^{\mathrm{lb}}$, a high $\mathrm{Li}^{+}$selectivity of the ion-selective electrodes (ISEs) is required because of interference from $\mathrm{Na}^{+}$which appears in high concentrations in body fluids. Kimura et al. ${ }^{2}$ applied 14-crown-4 (14C4) compounds to neutral carriers of liquid membrane-type ISEs and achieved high $\mathrm{Li}^{+}$ selectivity over $\mathrm{Na}^{+}$and $\mathrm{K}^{+}$. Recently, Hiratani et al. ${ }^{3}$ designed a series of acyclic compounds for neutral carriers (L, Fig. 1) to $\mathrm{Li}^{+}$-selective electrodes, and then examined potentiometrically the $\mathrm{Li}^{+}$selectivity of liquid membranetype ISEs with carriers I-VI. Especially, the $\mathrm{Li}^{+}$selectivity of ISEs with carriers I and II was comparable to that of ISEs with commercially-available $14 \mathrm{C} 4$ derivatives, such as dibenzyl-14C4 (DBz14C4) and phosphododecyl-14C4.2, $4^{a}$ In view of the modification of acyclic $\mathrm{L}$ for improving the $\mathrm{Li}^{+}$-selective electrode, it is interesting to study how the structure of $L$ enhances the stability of its $\mathrm{Li}^{+}$complex.

In the present study, we determined the stability constants of complexes of three acyclic neutral carriers (IV - VI) with $\mathrm{Li}^{+}$and $\mathrm{Na}^{+}$in a water-saturated nitrobenzene (NB) solution using the ion-transfer polarographic method, and calculated the potentiometric selectivity coefficients of IV - VI for $\mathrm{Li}^{+}$over $\mathrm{Na}^{+}$based on their stability constants. On the basis of these results, the structural effect of the six carriers (I - VI) on the stability constants are discussed.
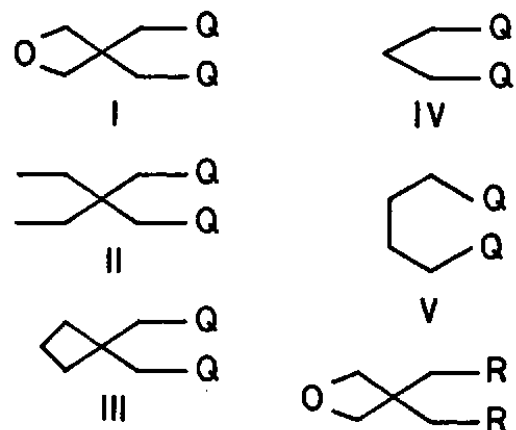

V

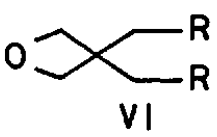

Q:

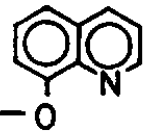

$\mathbf{R}$ :

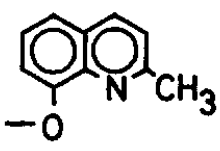

Fig. 1 Structural formulas of carriers I - VI employed. 


\section{Experimental}

\section{Chemicals}

Three carriers \{1,3-bis(8-quinolyloxy)propane (IV), 1,4-bis(8-quinolyloxy)butane (V) and 3,3-bis[(7-methyl8-quinolyloxy)methyl]oxetane (VI)\} were synthesized by a previously reported method. ${ }^{3}$ All other chemicals were of analytical grade and were used without further purification. The method of preparing all of the solutions used was the same as that described in a previous paper. ${ }^{4 a}$

\section{Electrochemical measurements}

The electrolytic cell with an electrolyte dropping electrode was the same as that described in a previous paper. ${ }^{5}$ The cell temperature was controlled at $25.0 \pm$ $0.5^{\circ} \mathrm{C}$ by circulating thermostated water through the jacket. A galvanic cell with the following characteristics was employed for controlling the measurements of the potential difference at the water (w)/NB-interface:

$$
\begin{aligned}
& \text { (RE 1) Ag }|\mathrm{AgCl}| \begin{array}{c}
0.05 \mathrm{~mol} \mathrm{dm}^{-3} \mathrm{TBACl} \\
\text { (phase: w) }
\end{array} \mid \\
& \underset{\substack{0.05 \mathrm{~mol} \mathrm{dm}^{-3} \mathrm{TBA} \cdot \mathrm{TPB} \\
0.2-0.6 \mathrm{mmol} \mathrm{dm}^{-3} \mathrm{~L}}}{\text { (NB) }}\left|\begin{array}{c}
c_{\mathrm{M}} \mathrm{MOH}+\mathrm{MCl} \\
(\mathrm{w})
\end{array}\right| \\
& \begin{array}{c|c|c|c|c}
\text { sat. } \mathrm{KCl} & 0.05 \mathrm{~mol} \mathrm{dm}^{-3} \mathrm{KCl} & \mathrm{AgCl} & \mathrm{Ag} & (\mathrm{RE} 2) \text {. }
\end{array}
\end{aligned}
$$

Here, the test interface is indicated by an asterisk and TBA-TPB denotes tetrabutylammonium tetraphenylborate as a supporting electrolyte in the NB-phase. The symbol $c_{\mathrm{M}}\left(0.03-0.7 \mathrm{~mol} \mathrm{dm}^{-3}\right)$ represents the bulk concentration of the metal (M) ion in the w-phase, which is in large excess compared with the concentration of $L$ in the NB-phase. The $\mathrm{pH}$ values of the w-phases containing either $\mathrm{LiOH}$ or $\mathrm{NaOH}$ were in the 8.8 to 11.8 range. All other procedures were the same as those described previously. ${ }^{4 a, 5}$ The values of the potential $(\Delta \phi)$ given in the present work were calculated in the same way as before ${ }^{5}$, and are designated as $\mathrm{V} v s$. TPh(As/ B)E (the $\mathrm{Ph}_{4} \mathrm{As}^{+} \mathrm{BPh}_{4}^{-}$electrode).

\section{Results and Discussion}

Representative polarograms for the $\mathrm{Li}^{+}-$and $\mathrm{Na}^{+}-\mathbf{I V}$ systems are shown in Fig. 2. Well-defined facilitated waves were observed in the range of 0 to $+0.2 \mathrm{~V} v s$. $\mathrm{TPh}(\mathrm{As} / \mathrm{B}) \mathrm{E}$; their diffusion-controlled limiting currents changed in proportion to the bulk concentration of IV. A log-plot analysis of the current-potential curves yielded straight lines with reciprocal slopes of $60 \pm 1 \mathrm{mV} /$ decade for the $\mathrm{Li}^{+}-\mathrm{IV}$ system $(n=15)$ and $59 \pm 1$ for the $\mathrm{Na}^{+}-\mathbf{I V}$ system $(n=13)$. Similar results were also obtained for the other systems; the reciprocal slopes were

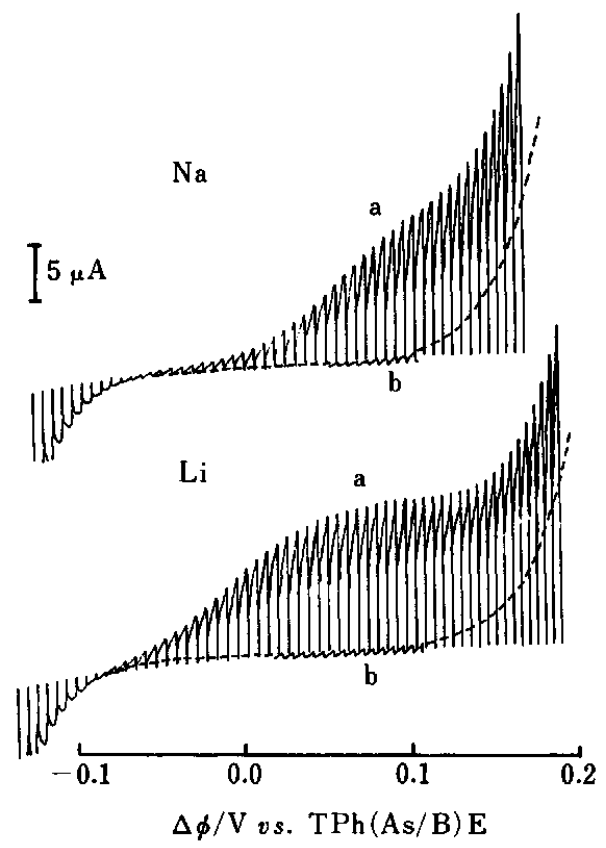

Fig. 2 Representative polarograms of $0.244 \mathrm{~mol} \mathrm{dm}^{-3} \mathrm{Li}^{+}$and $0.214 \mathrm{~mol} \mathrm{dm}^{-3} \mathrm{Na}^{+}$in the presence (curve a) and absence (b) of $0.372 \mathrm{mmol} \mathrm{dm}^{-3} \mathrm{IV}$ in the NB-phases. The reciprocal slopes $=60 \mathrm{mV} /$ decade $(\mathrm{Li})$ and $59(\mathrm{Na})$; the half-wave potentials $=-11 \mathrm{mV}(\mathrm{Li})$ and $55(\mathrm{Na})$.

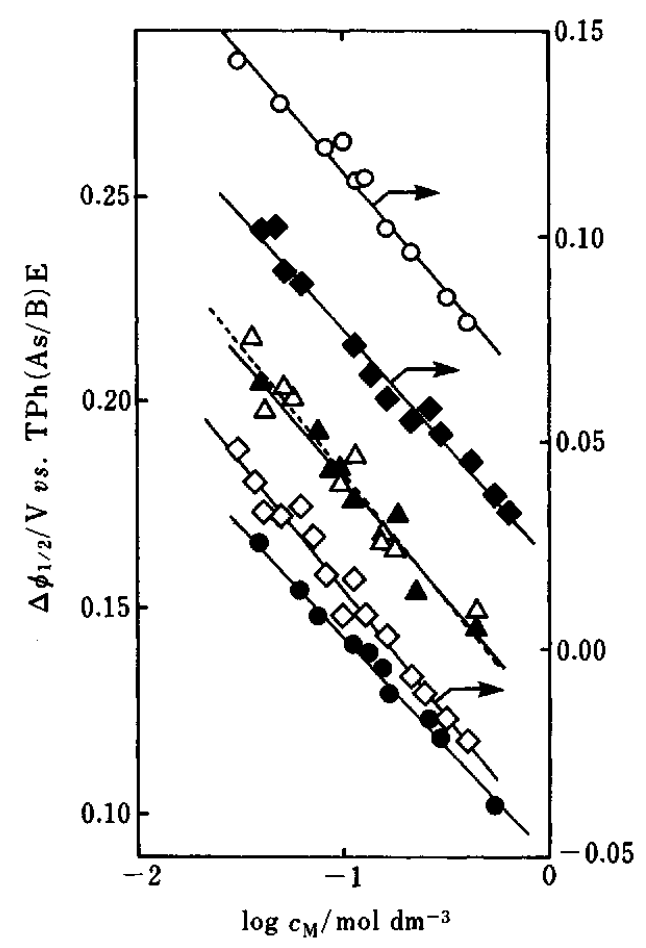

Fig. 3 Plots of $\Delta \phi_{1 / 2} v s$. $\log c_{\mathrm{M}}$ for carriers IV - VI. $\quad \mathrm{M}: \mathrm{Li}$ (open symbols); $\mathrm{Na}$ (solid symbols). The slopes of the straight lines: $-62 \mathrm{mV} /$ decade for the $\mathrm{Li}^{+}-\mathrm{IV}$ system (symbol: $\diamond) ;-56$ for $\mathrm{Na}^{+}-\mathrm{IV}(\diamond) ;-58$ for $\mathrm{Li}^{+}-\mathrm{V}(\mathrm{O}) ;-54$ for $\mathrm{Na}^{+}-\mathrm{V}$ $(\odot) ;-61$ for $\mathrm{Li}^{+}-\mathrm{VI}(\triangle)$ and -59 for $\mathrm{Na}^{+}-\mathrm{VI}(\Delta)$. 


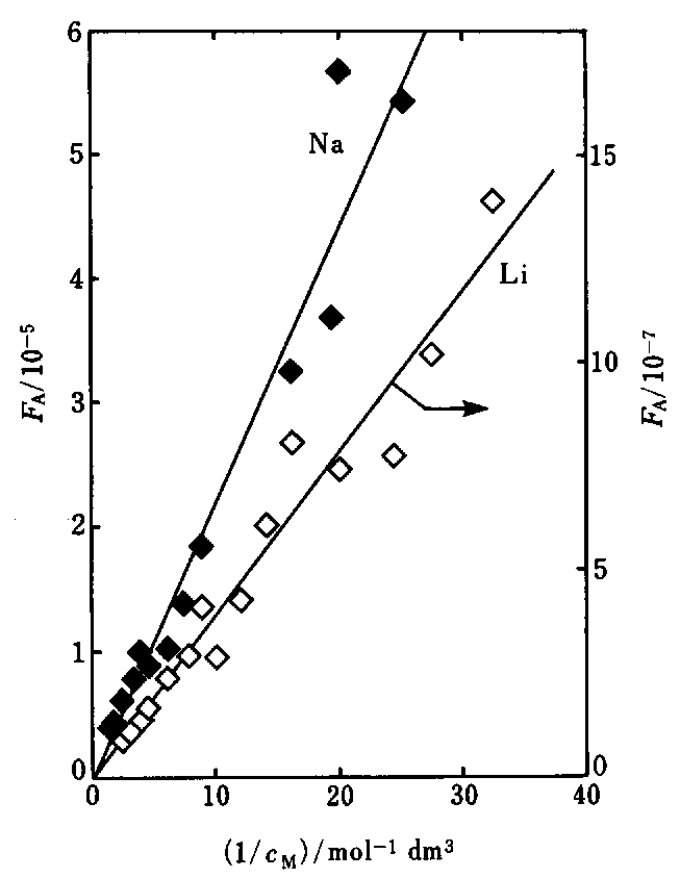

Fig. 4 Plots of $F_{\mathrm{A}} v s .1 / c_{\mathrm{M}}$ for the IV systems.

$59 \pm 0.4 \mathrm{mV} /$ decade for the $\mathrm{Li}^{+}-\mathrm{V}$ system (10), $58 \pm 2$ for $\mathrm{Na}^{+}-\mathrm{V}(10), 56 \pm 3$ for $\mathrm{Li}^{+}-\mathrm{VI}(11)$ and $57 \pm 3$ for $\mathrm{Na}^{+}-\mathrm{VI}$ (8). These results indicate that the facilitated waves are reversible and diffusion-controlled, and are caused by a transfer of a univalent cation across the w/NB-interface. ${ }^{5}$ Figure 3 shows half-wave potentials $\left(\Delta \phi_{1 / 2}\right)$ which depend on the logarithmic values of the $\mathrm{Li}^{+}$and $\mathrm{Na}^{+}$bulk concentrations. The slopes of the straight lines in Fig. 3 demonstrate that carriers IV - VI react with $\mathrm{Li}^{+}$and $\mathrm{Na}^{+}$ to form only $1: 1$ complexes in the water-saturated NBphase. $^{5}$

As described in a previous paper ${ }^{5}$, the function $F_{\mathrm{A}}$ $\left(=\exp \left[(z F / R T)\left(\Delta \phi_{1 / 2}-\Delta \phi_{M}^{o^{\prime}}\right)\right]\right)$ was plotted against $1 / c_{\mathrm{M}}$ (Fig. 4), where $\Delta \phi_{M}^{\circ}$ denotes the ion-transfer formal potential of the simple metal ion across the w/NBinterface: $\Delta \phi_{\mathrm{Li}}^{\circ}=0.395 \mathrm{~V}$ and $\Delta \phi_{\mathrm{Na}}^{\circ}=0.354 \mathrm{~V} v s$. TPh(As/ B)E. ${ }^{6}$ The plots yielded straight lines passing through the origin within the experimental errors. We can readily calculate the stability constants of $1: 1$ complexes in the water-saturated NB-phase from the slopes of the straight lines in Fig. 4, because the condition that carriers IV - VI possess high hydrophobic properties is satisfied. ${ }^{4 a}$ Table 1 lists the stability constants $\left(\beta_{1}^{\mathrm{NB}}(\mathrm{M}), \mathrm{M}=\mathrm{Li}\right.$ and $\mathrm{Na}$ ) of the complexes with IV - VI, together with those of the $1: 1$ complexes with the previously reported carriers I - III. ${ }^{4 a}$

The sequences of the $\beta_{1}^{\mathrm{NB}}$-values are IV $>$ III $>$ II $>$ $\mathbf{I}>\mathbf{V}>\mathbf{V I}$ for the $\mathrm{Li}^{+}$complexes and IV $>$III $>$V $>\mathbf{I}>$ II $>$ VI for the $\mathrm{Na}^{+}$complexes. A comparison of these two sequences indicates that an increase in the $\beta_{1}^{\mathrm{NB}}$-values of the $\mathrm{Li}^{+}$complexes due to a modification of $\mathrm{L}$ is in line with that of the $\mathrm{Na}^{+}$complexes, except for the II and $\mathbf{V}$ systems. For a given $\mathrm{L}$, the $\beta_{1}^{\mathrm{NB}}$-values of $\mathrm{Li}^{+}$complexes
Table 1 Stability constants of $1: 1$ complexes of $\mathrm{Li}^{+}$and $\mathrm{Na}^{+}$ with several acyclic carriers containing 8-quinolyloxy units in water-saturated $\mathrm{NB}$, and the selectivity coefficients for $\mathrm{Li}^{+}$over $\mathrm{Na}^{+}$at $25^{\circ} \mathrm{C}$

\begin{tabular}{lllc}
\hline \multicolumn{1}{c}{$\mathrm{L}$} & $\log \beta_{1}^{\mathrm{NB}}(\mathrm{Li})^{\mathrm{a}}$ & $\log \beta_{1}^{\mathrm{NB}}(\mathrm{Na})^{\mathrm{a}}$ & $\log k_{\mathrm{LiNa}}^{\text {pot }}$ \\
\hline $\mathbf{I}^{\mathbf{b}}$ & 6.4 & 4.4 & $-1.3(-1.5)^{\mathrm{c}}$ \\
II $^{\mathbf{b}}$ & 6.5 & 4.2 & $-1.6(-1.6)^{\mathrm{c}}$ \\
III $^{\mathrm{b}}$ & 7.2 & 5.3 & $-1.2(-1.1)^{\mathrm{c}}$ \\
IV $_{\text {V }}$ & $7.43 \pm 0.06^{\mathrm{d}}$ & $5.66 \pm 0.06^{\mathrm{d}}$ & $-1.1(-0.98)^{\mathrm{c}}$ \\
VI & $5.71 \pm 0.05^{\mathrm{d}}$ & $4.54 \pm 0.04^{\mathrm{d}}$ & $-0.5(-0.57)^{\mathrm{c}}$ \\
Without carrier & $4.58 \pm 0.09^{\mathrm{d}}$ & $3.90 \pm 0.06^{\mathrm{d}}$ & $0.0(-0.18)^{\mathrm{c}}$ \\
\hline
\end{tabular}

a. $\beta_{1}^{\mathrm{NB}}(\mathrm{M}) / \mathrm{mol}^{-1} \mathrm{dm}^{3}$.

b. Ref. $4 a$.

c. Values determined by potentiometry for the PVC-NPOE membrane electrodes. See Ref. 3.

d. Standard deviation.

are larger than the corresponding values of $\mathrm{Na}^{+}$complexes. From this result, we can see that carriers I-VI possess a high coordination ability for $\mathrm{Li}^{+}$over $\mathrm{Na}^{+}$.

According to an X-ray diffraction analysis ${ }^{7}$, a crystal of the complex of $\mathrm{LiClO}_{4}$ with IV has a five-coordinate structure with an $N, N, O, O$-tetradentate IV and a donor oxygen atom of $\mathrm{ClO}_{4}^{-}$. This result suggests that, in the NB-phase, I-VI give complexes with a coordination of $\mathrm{N}, \mathrm{N}, \mathrm{O}, \mathrm{O}$-tetradentate carriers in reacting with $\mathrm{Li}^{+}$.

The $\mathrm{Li}^{+}-\mathrm{IV}$ complex has the highest stability among the complexes of I-IV and VI containing the bis(8quinolyloxy)propane units in their molecules. Since the skeleton of IV may be the most flexible in I-IV and VI, the four donor atoms of IV can occupy the optimal position in coordinating with $\mathrm{Li}^{+}$. As can be seen from Table 1 , the $\beta_{1}^{\mathrm{NB}}$-value of the $\mathrm{Li}^{+}-\mathrm{IV}$ complex is much larger than that of the $\mathrm{Li}^{+}-\mathbf{V}$ complex. Furthermore, this value is close to that of $10^{7.0} \mathrm{~mol}^{-1} \mathrm{dm}^{3}$ for the $\mathrm{Li}(\mathrm{DBz} 14 \mathrm{C} 4)^{+}$complex ${ }^{4 a}$, in which $\mathrm{Li}^{+}$fits well into the cavity of the $14 \mathrm{C} 4$ ring. ${ }^{8,9}$ In explaining these observations, we point out that in the $\mathrm{Li}^{+}$complexes IV as a ligand can form a four-coordinate structure in a manner similar to that of the $O, O, O, O$-tetradentate $14 \mathrm{C} 4$, while $\mathrm{V}$ cannot form such a structure because of interference due to the butylene chain connecting the two 8quinolyloxy units.

The $\beta_{1}^{\mathrm{NB}}$-value of the $\mathrm{Li}^{+}-\mathrm{VI}$ complex is much smaller than that of the $\mathrm{Li}^{+}-\mathbf{I}$ complex (Table 1). In the $\mathrm{Li}^{+}-\mathrm{VI}$ complex, the steric hindrance between the methyl groups on the two quinolyloxy units prevents the carrier from forming a four-coordinate structure in a manner similar to that of the tetradentate $14 \mathrm{C} 4$. Due to this steric hindrance, the $\mathrm{Li}^{+}-\mathrm{N}$ bonds in the VI complex may be greatly weakened.

A similar discussion holds for the $\mathrm{Na}^{+}$complexes with carriers I, IV, V and VI.

We reported previously that the following equation can be used for calculating the potentiometric selectivity coefficients $\left(k_{\mathrm{LiNa}}^{\mathrm{pot}}\right)$ of ISEs containing neutral carriers: ${ }^{4}$ 


$$
\begin{aligned}
\log k_{\mathrm{LiNa}}^{\mathrm{pot}}= & \log \left(K_{\mathrm{D}, \mathrm{Na}} / K_{\mathrm{D}, \mathrm{Li}}\right) \\
& +\log \left[\beta_{\mathrm{I}}^{\mathrm{NB}}(\mathrm{Na}) / \beta_{1}^{\mathrm{NB}}(\mathrm{Li})\right]
\end{aligned}
$$

where $K_{\mathrm{D}, \mathrm{M}}(\mathrm{M}=\mathrm{Li}, \mathrm{Na})$ denotes the distribution constant $\left(c_{\mathrm{M}}^{\mathrm{NB}} / c_{\mathrm{M}}\right)$ of the simple metal ion between the $\mathrm{w}-$ and the NB-phases at the interfacial potential of $0 \mathrm{~V} v s$. $\mathrm{TPh}(\mathrm{As} / \mathrm{B}) \mathrm{E}$, and is related to $\Delta \phi_{\mathrm{M}}^{\circ}$ as follows: $\Delta \phi_{\mathrm{M}}^{\circ}=$ $-(2.3 R T / z F) \log K_{\mathrm{D}, \mathrm{M} .}{ }^{4 \mathrm{~b}, \mathrm{c}} \quad$ The value of $\log \left(K_{\mathrm{D}, \mathrm{Na}} / K_{\mathrm{D}, \mathrm{Li}}\right)$ is $+0.70 ; 4 b, c$ this positive value means that in the absence of $\mathrm{L}, \mathrm{Na}^{+}$transfers across the $\mathrm{w} / \mathrm{NB}$-interface more easily than does $\mathrm{Li}^{+}$. We can calculate the $\log k_{\mathrm{LiNa}}^{\text {pot }}$-values from the $\log \beta_{1}^{\mathrm{NB}}$-values using Eq. (1). As can be seen from the negative values of $\log k_{\mathrm{LiNa}}^{\mathrm{pot}}$ (summarized in Table 1), carriers I-VI in the NB-phase preferably facilitate the transfer of $\mathrm{Li}^{+}$across the w/NB-interface compared with that of $\mathrm{Na}^{+}$. Their facilitation effect is in the order $\mathbf{V I}<\mathbf{V}<$ IV $<$ III $<$ I $<$ II. This order is in accord with that of the $\mathrm{Li}^{+}$selectivity determined potentiometrically for the poly(vinyl chloride)-o-nitrophenyl octyl ether (PVC-NPOE) membrane ISEs. ${ }^{3}$

\section{References}

1. a) K. Nishizawa, “Kinōsei Daikanjyōkagōbutsu no BunsekiKagaku eno Öyo (Application of Functional Macrocyclic Compounds to Analytical Chemistry, in Japanese)", ed. Y. Takeda, Chap. 9, p. 431, IPC, Tokyo, 1990; b) R. W. Hay, "Bio-inorganic Chemistry", p. 200, Ellis Horwood, Chichester, 1987; c) M. Nishimura, "Environmental Chemistry (in Japanese)", Chap. 2, p. 20, Shokabo, Tokyo, 1991.
2. a) K. Kimura, H. Yano, S. Kitazawa and T. Shono, J. Chem. Soc., Perkin Trans. II, 1986, 1945; b) K. Kimura and T. Shono, "Cation Binding by Macrocycles: Complexation of Cationic Species by Crown Ethers", ed. Y. Inoue and G. W. Gokel, Chap. 10, p. 429, Marcel Dekker, New York, 1990.

3. a) K. Hiratani, Yuki Gosei Kagaku Kyokai Shi, 45, 1186 (1987); b) K. Hiratani, T. Okada and H. Sugihara, Anal. Chem., 59, 766 (1987).

4. a) Y. Kudo, Y. Takeda, K. Hiratani and H. Matsuda, Anal. Sci., 7, 547 (1991); b) Y. Kudo, Y. Takeda and H. Matsuda, Bunseki Kagaku, 40, 779 (1991); c) Y. Kudo, T. Kobayashi, T. Ezaki, I. H. Refaat, Y. Takeda and H. Matsuda, Anal. Sci., 10, 129 (1994).

5. H. Matsuda, Y. Yamada, K. Kanamori, Y. Kudo and Y. Takeda, Bull. Chem. Soc. Jpn., 64, 1497 (1991).

6. T. Kakutani, Y. Nishiwaki, T. Osakai and M. Senda, Bull. Chem. Soc. Jpn., 59, 781 (1986); T. Osakai, T. Kakutani, Y. Nishiwaki and M. Senda, Anal. Sci., 3, 499 (1987).

7. K. Ueno, K. Hiratani, K. Taguchi, T. Okada and H. Sugihara, Chem. Lett., $1987,949$.

8. C. J. Pedersen, Fed. Proc., Fed. Am. Soc. Exp. Biol., 27, 1305 (1968); Y. Takeda, Bull. Chem. Soc. Jpn., 53, 2393 (1980); S. Ogawa, R. Narushima and Y. Arai, J. Am. Chem. Soc., 106, 5760 (1984).

9. Molecular structures of the $1: 1$ complexes of $\mathrm{Li}^{+}$with the $14 \mathrm{C} 4$ derivatives have been reported. In the crystal of $\mathrm{Li}$ (benzo-14C4) $\mathrm{NO}_{3}$, benzo-14C4 acts as an $O, O, O, O$ tetradentate ligand, forming the six-coordinate complex containing a bidentate $\mathrm{NO}_{3}{ }^{-}$. See, U. Olsher, R. $\mathrm{M}$. Izatt, J. S. Bradshaw and N. K. Dalley, Chem. Rev., 91, 137 (1991). 